\title{
Evaluation of Anti Diabetic Activity of Ethanolic Seed Extract of Datura Innoxia Mill.
}

\author{
Jincy Thomas ${ }^{1, *}$, A. Srinivas ${ }^{2}$, Folitartha Roy ${ }^{3}$ \\ ${ }^{1}$ Department of Pharmacology, College of Pharmaceutical Sciences, Dayanada Sagar University, Bengaluru, Karnataka, India \\ ${ }^{2}$ Principal of Sree Dattha Institute of Pharmacy, Hyderabad, Telangana, India \\ ${ }^{3}$ Department of Pharmacology, Himalayan University, Jullang, Arunachal Pradesh, India
}

Received June 14, 2021; Revised August 31, 2021; Accepted February 21, 2022

\section{Cite This Paper in the following Citation Styles}

(a): [1] Jincy Thomas, A. Srinivas, Folitartha Roy, "Evaluation of Anti Diabetic Activity of Ethanolic Seed Extract of Datura Innoxia Mill.," Advances in Pharmacology and Pharmacy, Vol. 10, No. 1, pp. 69 - 75, 2022. DOI: 10.13189/app.2022.100106.

(b): Jincy Thomas, A. Srinivas, Folitartha Roy (2022). Evaluation of Anti Diabetic Activity of Ethanolic Seed Extract of Datura Innoxia Mill.. Advances in Pharmacology and Pharmacy, 10(1), 69 - 75. DOI: 10.13189/app.2022.100106.

Copyright $\bigcirc 2022$ by authors, all rights reserved. Authors agree that this article remains permanently open access under the terms of the Creative Commons Attribution License 4.0 International License

\begin{abstract}
The current research has been performed to substantiate the traditional claim of the anti-diabetic activity of seeds of Datura Innoxia Mill. in rats. This plant contains scopolamine alkaloid, which has been reported to be used in operations as pre-anaesthesia, used in delivery, as well as in ocular surgeries and for travel sickness prophylaxis. Datura is a medicinal and hallucinogenic plant that is used everywhere in the globe. Datura is revered in Ayurveda because all parts of the plant have medicinal properties, including the roots, leaves, seeds, and flowers, and have been employed to treat a variety of ailments, including leprosy, rabies, and insanity. Withanolide has recently been found to have potent anti-tumor, anti-inflammatory, anti-bacterial, hepatoprotective, soporfic, cytotoxic, and immune suppressant properties. An alloxan-induced diabetes model in rats was used to test the anti-diabetic activity of an ethanolic extract of the seeds of Datura Innoxia Mill. (Family-Solanaceae). A comparison was made between both the animals treated with extract from seeds and animals treated with known drug for diabetes i.e.., glibenclamide. The extract dose was chosen based on acute oral toxicity tests conducted in accordance with OECD norms. The outcomes revealed the fact that ethanolic extract significantly reduced the glucose levels in blood. The findings supported the use of seeds extract in the treatment of diabetes.
\end{abstract}

Keywords Datura Innoxia Mill, Alloxan Monohydrate, Glibenclamide, Glucose, Glucometer

\section{Introduction}

Diabetes mellitus (DM) is a worldwide health problem, which is becoming more prevalent as a source of morbidity and mortality [1]. About $5 \%$ to $8 \%$ of the population has diabetes. Many people are asymptomatic and unaware that they have the condition [2]. Obesity is to blame for much of the recent and expected increase in diabetes diagnoses in the United States. Diabetes is the $3^{\text {rd }}$ greatest illness as a cause of death, the $2^{\text {nd }}$ largest cause of renal fiasco and of blindness, despite the fact that insulin therapy has significantly increased diabetes patients' expectation of life [3].

The prevalence of diabetes mellitus (DM) is rising dramatically in developed countries, owing primarily to lifestyle changes and the associated rise in obesity. The metabolic repercussions of long-term hyperglycemia and dyslipidemia, such as accelerated atherosclerosis, chronic renal disease, and blindness, place a huge burden on diabetic individuals and society. To face this challenge, we must improve our understanding of the pathophysiology of diabetes and its consequences, as well as diabetes prevention and treatment [4].

Because of its cultural acceptance, and compatibility to humans, and lack of negative consequences, herbal medicine is still the primary source of basic health care for around $75-80 \%$ of the population of the globe, mostly in 
underdeveloped countries [5]. Herbal medicine is also known as neutraceuticals (health foods), with a current market value of \$ 80-250 billion in the United States and Europe [6]. Medicinal plants are found across the world, although they are most numerous in tropical areas. Higher plants are thought to be the source of around $25 \%$ of all contemporary medications, either directly or indirectly [7].

Literature survey has revealed that amongst many unexplored plants, Datura Innoxia Mill (Solanaceae) is a valuable medicinal plant used traditionally as well as in modern medicine [8, 9]. In Ayurveda, Datura Innoxia Mill is called it 'Dhattuura'. Datura Innoxia Mill is an annual shrubby plant that typically grows in temperature zones [10]. The native range of Datura Innoxia Mill appears to have been Mexico and the U.S. Southwest, the Caribbean Islands, India and China [11]. The plant has anti-viral, anti-cancer activity, wound healing properties, antiperspirant activity, hypoglycaemic effect immunomodulatory effect and anti-ulcer and anti- stress activity [12]. The alkaloid scopolamine is found in the plant and is used as a pre-anesthetic in abscission, parturition, ocular operations, and travel sickness prophylaxis [13, 14, 15]. There has been a recent movement in the worldwide shift from synthetic to natural medicine, which we call a "Return to Nature."

Due to a growing awareness in terms of health risks connected with the aimless application of modern therapy, there is a resurgence of interest in herbal-based treatment these days, and the herbal medicine industry is currently a rapidly expanding sector in the worldwide market [16]. Herbal medication use is on the rise, and the market is expanding at a steady pace [17].

\section{Materials and Procedure}

\subsection{Collection}

The dried seeds of Datura Innoxia were gathered from Dr.Madhavachetty, Department of Botany, SV.University, Tirupathi.

\subsection{Identification}

The collected seeds were identified and authenticated as Datura Innoxia Mill by Dr.Madhavachetty

\subsection{Size Reduction}

The dried seeds were coarsely powdered.

The extracts of powdered Datura Innoxia Mill were used in this study. Sequential soxhalation extraction with ethanol solvent was used to prepare the seeds. The finely powdered Datura Innoxia Mill seeds were loaded in the thimble and fit into the soxhlet apparatus. The drug-to-solvent ratio of 1:3 was maintained throughout the extraction procedure with each solvent (ethanol, chloroform, methyl alcohol) for 24 hours. The Whatmann No. 1 filter paper was used to filter the contents after 24 hours and sterilised muslin cloth, as needed. Filtrate obtained was evaporated on water bath and dried at $37^{\circ} \mathrm{C}$ and stored at $4^{\circ} \mathrm{C}$ until used.

\section{Preliminary Phytochemical Screening: [18, 19, 20, 21]}

The existence of phyto substances like Sterols, Reducing agents, phenolic compounds, Glycosides, Alkaloids, Flavanoids, Saponins, Proteins and carbohydrates were investigated in preliminary assays [22].

\section{Pharmacological Studies}

\subsection{Acute Toxicity Studies [23] \\ OECD Guidelines for Acute Toxicity Studies:}

The extracts were put to the test for acute oral toxicity according to OECD criteria. The Ministry of Social Justice and Empowerment's Committee for the Purpose of Supervision and Control of Experiments on Animals (CPCSEA), provided draught guidelines 423 , which were adopted and received. The evaluated animals showed no symptoms of toxicity after receiving stepwise dosages of Datura Innoxia extracts ranging from $50 \mathrm{mg} / \mathrm{kg}$ body weight to $2000 \mathrm{mg} / \mathrm{kg}$ body weight.

Four sets of wistar strain male rats having four rats in each set are taken, of which one of the groups is considered as control and given normal saline. The rest three sets are administered with the extract of Datura innoxia seed in graded doses of 50, 300, and $2000 \mathrm{mg} / \mathrm{kg}$ sequentially as per OECD guidelines 423 . Up to 14 days after receiving the plant extract, the animals were monitored for any changes in behaviour or mortality.

\subsection{Test for Glucose Tolerance [24]}

The Test for Glucose Tolerance was done on many sets of rats.

Group-I: Standard group (control) animals received glucose, intraperitonially.

Group-II: Glibenclamide treated animals received glucose intraperitonially.

Group-III: Extract treated animals received glucose, intraperitonially.

\section{Procedure:}

Fast rats for 16-18 hours. Ensure that they have access to drinking water all the time. On the following day, at 
8:00 AM, lay the mice individually in neat cages with only water. Numbers are given to identify the different cages. Arrange the procedure sheet, needle and sticks for determining blood glucose levels and track record the weight of each rat. Measure and track of the amount of glucose needed. (2g glucose/kg) for Intraperitoneal injection as follows: volume of Intraperitoneal glucose injection $(\mathrm{ml})=10 \times$ body $\mathrm{wt}(\mathrm{g})$. Place rats in the confinement cage exposing the tail outside. Use a sterile scalpel blade and scratch the tail's tip. On the test strip, place a drop of blood and check on the glucose meter. It is recorded as the glucose level base line $(\mathrm{t}=0)$ in the experiment record sheet. Take out the rat from the confinement cage. As previously said (point 4), inject the rat intraperitoneally with the necessary quantity of glucose and mark the time of administration on a record sheet. Using a fresh test strip and a tiny amount of blood, record the readings at $15,30,60$, and 120 minutes after glucose administration. Remove the clot from the first incision to re-start the flow. The results are written down on the record sheet.

Apply pressure to the incision for 1-2 minutes after each measurement to prevent further blood loss. Place the rats in a clean cage at the end of the experiment and ensure that they have access to plenty of water and food.

\subsection{Alloxan Induced Antidiabetic Activity: [25, 26]}

\subsubsection{Induction of diabetes:}

Fasted albino rats were induced diabetic overnight by administering $100 \mathrm{mg} / \mathrm{kg}$ body weight alloxan monohydrate intraperitonially. Alloxan was weighed separately for each animal based on its body weight, then it was dissolved in $0.2 \mathrm{ml}$ saline solution right before inoculation. After 72 hours the rats with sugar level more than $180 \mathrm{mg} / \mathrm{dl}$ were utilised in this research.

Design of the study:

Overnight fasted animals were dispersed randomly, and each group consists of five rats.

Group 1: normal rats receiving medium (vehicle).

Group 2: Diabetis treated group (control) which receives alloxan monohydrate and vehicle.

Group 3: The ethanolic extract of seeds of low dose was used to treat this diabetic group.

Group 4: The ethanolic extract of seeds of high dose was used to treat this diabetic rats group

Group 5: This group of diabetic rats are treated with glibenclamide.

After overnight fasting, the animals receive vehicle and drugs orally using intragastric tubes daily for three weeks.

\subsubsection{Blood glucose estimation: [27]}

To determine blood glucose level, the samples of blood are collected on 0 day, $7^{\text {th }}$ day, $14^{\text {th }}$ day and $21^{\text {st }}$ day. By rupturing the tail vein, the blood was extracted. One touch glucometers and blood glucose checkup strips were used to measure blood glucose levels.

\section{Results and Discussion}

\subsection{Phytochemical Investigation}

The existence of phytosubstances like Sterols, Reducing agents, phenolic compounds, Glycosides, Alkaloids, Flavanoids, Saponins, Proteins and carbohydrates were carried out in preliminary assays.

In the preliminary investigation on the ethanolic seed extract of the DI, it reveals the existence of steroids, alkaloids, glycosides, flavonoids and tannins.

The result of chemical test of chemical test methanolic seed extract of Datura innoxia mill is shown in Table 1.

Table 1. Preliminary phyto chemical screening

\begin{tabular}{|c|c|}
\hline Type of phyto constituent & EXTRACT OF ETHANOL \\
\hline Proteins & $\mathrm{AB}$ \\
\hline Phenolic Compounds & $\mathrm{AB}$ \\
\hline Flavanoids & $\mathrm{SP}$ \\
\hline Triterpenoids \& steroids & $\mathrm{SP}$ \\
\hline Tannins & $\mathrm{SP}$ \\
\hline Cardiac glycosides & $\mathrm{SP}$ \\
\hline Alkaloids & $\mathrm{MP}$ \\
\hline Saponins & $\mathrm{MP}$ \\
\hline Carbohydrates & $\mathrm{MP}$ \\
\hline Fixed oils & $\mathrm{MP}$ \\
\hline Glycosides & $\mathrm{MP}$ \\
\hline
\end{tabular}

Absent; SP: Slightly Present; MP: Moderately Present.

\subsection{Acute Toxicity Studies:}

The rats utilised in the study were chosen using a random sampling procedure. The OECD-423 guidelines were followed for acute oral toxicity testing. The male Wistar strain rats were divided into three groups and are given extract of datura innoxia seed with graded doses of 50, 300, and $2000 \mathrm{mg} / \mathrm{kg}$ p.o., sequentially, in this toxicity research. The fourth group is considered as control and given normal saline. The drug was administered orally to the rats of three groups. Prior to administration of the medication the rats are fasted overnight with water ad libitum. Animals were maintained under observation for 14 days to see if their behaviour changed or if they died, as shown in Table 2.

\subsection{Glucose tolerance test:}

The highest amount of glucose in blood climbed quickly compared to the fasting result at 30 minutes after glucose injection, then dropped. The ethanolic extract of 
Datura Innoxia Mill at 60 and 120 minutes showed a on extract on glucose tolerance, which is summarized in substantial drop in glucose levels in blood and the effect Table 3.

Table 2. Observations of studies on the acute toxicity of an ethanolic extract of Datura Innoxia Mill

\begin{tabular}{|c|c|c|c|c|c|c|c|c|}
\hline S.NO. & Treatment & Dose & $\begin{array}{c}\text { Weight } \\
\text { of the } \\
\text { animal } \\
\text { (Day1) }\end{array}$ & $\begin{array}{c}\text { Weight } \\
\text { of the } \\
\text { animal } \\
\text { (Day 14) }\end{array}$ & $\begin{array}{c}\text { Signs of } \\
\text { Toxicity }\end{array}$ & $\begin{array}{c}\text { Onset of } \\
\text { toxicity }\end{array}$ & $\begin{array}{c}\text { Reversible } \\
\text { Or irreversible }\end{array}$ & Duration \\
\hline 1. & $\begin{array}{c}\text { DATURA } \\
\text { INNOXIA }\end{array}$ & $50 \mathrm{mg} / \mathrm{kg}$ & $150 \mathrm{gm}$ & $158 \mathrm{gm}$ & NIL & NIL & NIL & 14 Days \\
\hline 2. & $\begin{array}{c}\text { DATURA } \\
\text { INNOXIA }\end{array}$ & $50 \mathrm{mg} / \mathrm{kg}$ & $150 \mathrm{gm}$ & $152 \mathrm{gm}$ & NIL & NIL & NIL & 14 Days \\
\hline 3. & $\begin{array}{l}\text { DATURA } \\
\text { INNOXIA }\end{array}$ & $50 \mathrm{mg} / \mathrm{kg}$ & $150 \mathrm{gm}$ & $154 \mathrm{gm}$ & NIL & NIL & NIL & 14 Days \\
\hline 4. & $\begin{array}{l}\text { DATURA } \\
\text { INNOXIA }\end{array}$ & $300 \mathrm{mg} / \mathrm{kg}$ & $150 \mathrm{gm}$ & $153 \mathrm{gm}$ & NIL & NIL & NIL & 14 Days \\
\hline 5. & $\begin{array}{l}\text { DATURA } \\
\text { INNOXIA }\end{array}$ & $300 \mathrm{mg} / \mathrm{kg}$ & $150 \mathrm{gm}$ & $151 \mathrm{gm}$ & NIL & NIL & NIL & 14 Days \\
\hline 6. & $\begin{array}{l}\text { DATURA } \\
\text { INNOXIA }\end{array}$ & $300 \mathrm{mg} / \mathrm{kg}$ & $150 \mathrm{gm}$ & $155 \mathrm{gm}$ & NIL & NIL & NIL & 14 Days \\
\hline 7. & $\begin{array}{l}\text { DATURA } \\
\text { INNOXIA }\end{array}$ & $2 \mathrm{~g} / \mathrm{kg}$ & $140 \mathrm{gm}$ & $143 \mathrm{gm}$ & NIL & NIL & NIL & 14 Days \\
\hline 8. & $\begin{array}{l}\text { DATURA } \\
\text { INNOXIA }\end{array}$ & $2 \mathrm{~g} / \mathrm{kg}$ & $140 \mathrm{gm}$ & $146 \mathrm{gm}$ & NIL & NIL & NIL & 14 Days \\
\hline 9. & $\begin{array}{l}\text { DATURA } \\
\text { INNOXIA }\end{array}$ & $2 \mathrm{~g} / \mathrm{kg}$ & $140 \mathrm{gm}$ & $141 \mathrm{gm}$ & NIL & NIL & NIL & 14 Days \\
\hline
\end{tabular}

NIL - Indicates no toxicity

Table 3. Observations of glucose tolerance test of ethanolic seed extract of Datura Innoxia Mill.

\begin{tabular}{|c|c|c|c|c|c|c|}
\hline \multirow{2}{*}{ GROUPS } & \multirow{2}{*}{$\begin{array}{c}\text { NUMBER OF } \\
\text { ANIMALS }\end{array}$} & \multicolumn{5}{|c|}{ Average BLOOD GLUCOSE LEVELS(mg/dl) } \\
\cline { 3 - 7 } & 3 & $\mathbf{0 m i n}$ & $\mathbf{1 5 m i n}$ & $\mathbf{3 0 m i n}$ & $\mathbf{6 0 m i n}$ & $\mathbf{1 2 0 m i n}$ \\
\hline Control group & $36 \pm 5.567$ & $127 \pm 2.64$ & $123.7 \pm 11.15$ & $97 \pm 2$ & $89 \pm 5$ \\
\hline $\begin{array}{c}\text { Glibenclamide treated } \\
\text { group }\end{array}$ & 3 & $85.67 \pm 3.512$ & $122 \pm 6.55$ & $128 \pm 1$ & $96.67 \pm 4.16$ & $91 \pm 3.6$ \\
\hline Extract treated group & 3 & $86 \pm 4.583$ & $113 \pm 2$ & $128.67 \pm 1.52$ & $101.67 \pm 8.02$ & $88.67 \pm 3.51$ \\
\hline
\end{tabular}

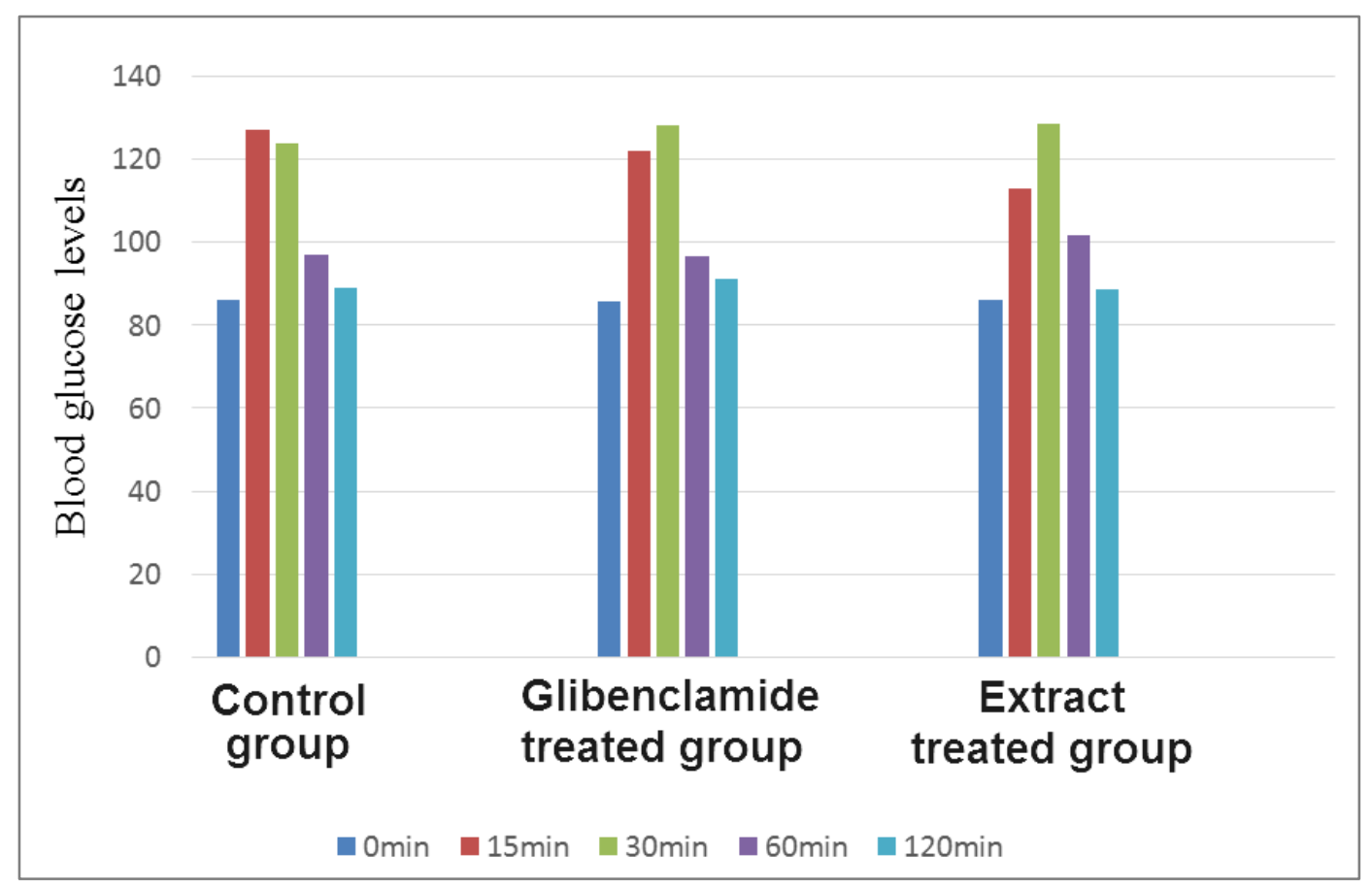

Figure 1. The chart representing the Glucose Tolerance test of Datura Innoxia Mill 
Table 4. Observations on the anti diabetic efficacy of Datura Innoxia Mill ethanolic seed extract

\begin{tabular}{|c|c|c|c|c|c|c|c|}
\hline \multirow{2}{*}{ Groups } & \multirow{2}{*}{$\begin{array}{c}\text { Number } \\
\text { of } \\
\text { Animals }\end{array}$} & \multirow{2}{*}{ Dose } & \multirow{2}{*}{$\begin{array}{c}\text { Average } \\
\text { weight of } \\
\text { animals }\end{array}$} & \multicolumn{4}{|c|}{ Average Blood Glucose Values (mg/dL) } \\
\hline & & & & 0 day & $7^{\text {th }}$ day & $14^{\text {th }}$ day & $21^{\text {st day }}$ \\
\hline Control group & 5 & $1 \%$ & $154 \mathrm{gms}$ & $94.4 \pm 14.976$ & $87.8 \pm 10.69$ & $92.8 \pm 15.34$ & $90.2 \pm 8.87$ \\
\hline $\begin{array}{c}\text { Diabetic treated } \\
\text { group }\end{array}$ & 5 & $100 \mathrm{mg} / \mathrm{kg}$ & 167gms & $303.2 \pm 36.30$ & $314.4 \pm 38.71$ & $319.4 \pm 38.13$ & $323.8 \pm 41.92$ \\
\hline $\begin{array}{l}\text { Glibenclamide } \\
\text { treated group }\end{array}$ & 5 & $5 \mathrm{mg} / \mathrm{kg}$ & 145 gms & $278.8 \pm 8.98$ & $195 \pm 31.57$ & $138 \pm 15.70$ & $97.8 \pm 16.54$ \\
\hline $\begin{array}{l}\text { Test group (low } \\
\text { dose) }\end{array}$ & 5 & $200 \mathrm{mg} / \mathrm{kg}$ & 149gms & $258 \pm 17.47$ & $187.2 \pm 14.30$ & $158.8 \pm 23.004$ & $116.8 \pm 11.84$ \\
\hline $\begin{array}{l}\text { Test group (high } \\
\text { dose) }\end{array}$ & 5 & $400 \mathrm{mg} / \mathrm{kg}$ & 164gms & $268.8 \pm 18.75$ & $189.4 \pm 24.33$ & $155.2 \pm 25.91$ & $112.8 \pm 16.3003$ \\
\hline
\end{tabular}

\subsection{Anti-Diabetic Activity}

After the diabetes has been induced, the rats, with hyperglycemia were utilised for the study. The animals included in the control group showed normal amounts of glucose in blood whereas the diabetic group (negative control group) animals, and high amounts of glucose in blood. The ethanolic seed extract of datura innoxia treated group (DI $200 \mathrm{mg} / \mathrm{kg}, 400 \mathrm{mg} / \mathrm{kg}$ oral) dose dependently showed significantly $(\mathrm{p}<0.01)$ (ANOVA test) reduction in the blood glucose levels. The standard anti-diabetic drug glibenclamide showed significantly greater $(p<0.01)$ hypoglycemic effect. The findings are summarized in Table 4.

\section{Discussion}

The medical system still faces a problem in managing diabetes using medications that have no adverse effects. This issue has resulted in a rise in demand for natural anti-hyperglycemic treatments with fewer adverse effects.

Insulin-producing beta cells in the pancreas are destroyed by alloxan, which causes diabetes [28, 29]. Alloxan is preferentially harmful to beta cells in the pancreas, resulting in necrosis of cells, according to in vitro investigations [30,31]. Alloxan's cytotoxic impact is arbitrated by oxygen reactive species, which causes huge rise in calcium content in the cytosol, causing beta cells to die quickly [32].

The ability of a plant extract to cause $\beta$-cells to generate insulin or to stimulate insulin receptors, which allows blood sugar to be absorbed and accelerate glucose consumption in the peripheral tissues could also provide antihyperglycemic effects [33].

The ethanol seed extract of Datura Innoxia Mill provided orally for 21 days led in a considerable drop in glucose levels in the blood in an alloxan induced diabetes type and a glucose tolerance test in rats, according to the current research. Similar impact of the plant extracts on glibenclamide could indicate a similar mechanism of action. As a result, the current study backs up the traditional assertion that Datura Innoxia Mill has anti-diabetic properties [34].

The preliminary assays, proved that Datura Innoxia contains saponins, alkaloids, cardiac glycosides, flavonoids. The presence of these elements could possibly explain the extract's anti-diabetic properties.

Anti-diabetic properties of the extract could be related to effects such as encouraging -cell regeneration or protecting them from damage, limiting glucose load, and promoting unconstrained endogenous insulin action. The ability of plant extract on $\beta$-cells to generate insulin or stimulate insulin receptors to absorb blood glucose and accelerate glucose consumption in periphery could also be responsible for the anti-hyperglycemic effect.

The plant extract has shown no toxic effects on animals when treated maximum dose. It proves that it has a safe and broad therapeutic index. It is also shown from the glucose tolerance studies that the drug is not elevating the glucose levels. The main activity has proved that the drug has anti diabetic activity, with very minimal side effects or no side effects and most important and it is safe with maximum dose.

\section{Conclusions}

In conclusion, the present study systematically investigated the anti-diabetic potential of ethanolic seed extract of Datura Innoxia Mill., and supports its traditional use as anti-diabetic medicine.

Therefore, it means that Datura Innoxia have anti-diabetic activity and because of the anti hyperglycemic properties, when compared to manufactured medicines, medicinal plants have fewer negative effects, tremendous expense of contemporary medicines, and many rural communities in underdeveloped nations lack access to modern medicines, which could be considered a substitute for conventional diabetes mellitus treatment. The findings suggest that Datura Innoxia Mill seed extracts have anti-diabetic effect. 


\section{REFERENCES}

[1] Chang-Yu Pan, Yan Gao, Jia-Wei Chen, Bang-Yao Luo, Zu-Zhi Fu, Ju-Ming Lu, Xiao-Hui Guo, Hua Cheng. Efficacy of acarbose in Chinese subjects with impaired glucose tolerance. Diabetes Research and clinical practice, 2003 Sep; 61(3): 183-90.https://pubmed.ncbi.nlm.nih.gov/ 12965108/ PMID: $12965108 . \quad$ DOI: 10.1016/s0168-8227(03)00117- 7

[2] George A. Beller, MD and Jamieson M. Bourque, MD, MHS Screening Asymptomatic Patients With Type-2 Diabetes: The Debates Persist PMCID: PMC4827434 NIHMSID: NIHMS772182, PMID: 26391501

[3] Charles R. Craig, Robert E. Stitzel. Chapter 67, "Insulin and Oral Drugs for Diabetes Mellitus” in "Text book of modern pharmacology with clinical applications”, $5^{\text {th }}$ edition pg.no. 766, 767. Lippincott Williams publisher.

[4] Laurence L Brunton; Louis Sandford Goodman; Alfred Goodman Gilman; Keith L Parker Chapter 60, INSULIN, ORAL HYPOGLYCEMIC AGENTS, AND THEPHARMACOLOGY OF THE ENDOCRINE PANCREAS in "Manual of Pharmacology and Therapeutics pg.no. 1037 New York: McGraw-Hill, (C2008. DOI: $10.1036 / 0071443436$

[5] “Botanical Review”, vol- 47: 421- 450, 1981 Published by: Springer on behalf of New York Botanical Garden Presshttps://www.jstor.org/stable/i398308

[6] Drissa Diallo, Britt Hveem, Mohamed Ag Mahmoud, Gunnvor Berge, Berit Smestad Paulsen \& Aboubacar Maiga "An Ethanobotanical Survey of Herbal drugs of Gourma District”, mali pharmaceutical biology; vol-37: 80-91, 1999. Pages 80-91 | Published online: 29 Sep 2008

[7] https://www.tandfonline.com/doi/abs/10.1076/phbi.37.1.80 .6313https://doi.org/10.1076/phbi.37.1.80.6313

[8] Mahesh B, Sathish S, “Antimicrobial activity of some important medicinal plant against plant and human pathogens", World Journal of Agriculture Science; vol 4(5), 839-843, 2008.

[9] P.kaushik, pankaj goyal, in vitro evaluation of Datura innoxia (thorn apple) for potential antibacterial activity. Indian j. microbial. Sep (2008) 48: 353-357. Published online 2008 Jun https://www.ncbi.nlm.nih.gov/pmc/article s/PMC3476774/doi: 10.1007/s12088-008-0020-7PMCID: PMC3476774 PMID: 23100734

[10] Ali Hazrat, Mohammad Nisar, Jehandar Shah, and Shujaat Ahmad. Ethnobotanical study of some elite plants belonging to dir, kohistan valley. Pakistan journal. Bot., 43(2): 787-795,2011https://www.researchgate.net/publicat ion/228512941_Ethnobotanical_study_of_some_elite_plan ts_belonging_to_dir_Kohistan_Valley_Khyber_Pukhtunkh wa_Pakistan

[11] Hashim Ahmed EL-Massad Abdalla Abdelrahim Satti and Zuhair Alfadel Alabjar. Insecticidal potentiality of datura innoxia leaf extracts against the cluster bug. Global advanced research journals 2012. https://www.researchgate.net/publication/271510558_Inse cticidal_potentiality_of_Datura_innoxia_leaf_extracts_aga inst_the_cluster_bug_Agonoscelis_pubescens_Thunberg
[12] Rawia Zayed, Michael Wink, Hesham El-Shamy invitro organogenesis and alkaloid accumulation in Datura innoxia. Indian j.microbial. sep (2008)48: 353-357. https://pubmed.ncbi.nlm.nih.gov/16989317/PMID:169893 17. DOI: 10.1515/znc-2006-7-815

[13] Neeraj O. Maheshwari, Ayesha Khan and Balu A. Chopade. Rediscovering the medicinal properties of Datura species. Academic journal vol.7(39), pp.2885-2897, 17 October, 2013 DOI: 10.5897/JMPR11.1657 ISSN 1996-0875 @2013 Academic Journals http://www.academicjournals.org/JMP $\mathrm{R}$

[14] C.P. Khare Indian Medicinal Plants: An Illustrated Dictionary Indian Medicinal Plants,pg no: 202, publisher, Springer Science \& Business Media, 2008, ISBN0387706372, 9780387706375 ISBN - 978-0-387-70637-5 Springer-Verlag Berlin/Heidelberg

[15] http://www.usda.gov.org/ plant profile.html / Datura Innoxia

[16] http://www.missouribotanicalgarden.org , PlantFinder Datura Innoxia

[17] Satakopan S, "Pharmacopeial Standards for Ayurvedic, Siddha and Unani Drugs”, In Proceedings of WHO Seminar on Medicinal Plants and Quality Control of Drugs Used in ISM. Ghaziabad, 1994.

[18] Kamboj VP, "Herbal Medicine”, Current Science; vol-78(1): 35-39, 2000.

[19] Ayuba V.O., Ojobe T.O., and Ayuba S.A. Phytochemical and proximate composition of Datura innoxia leaf, seed, stem, pod and root. Journal of Medicinal Plants Research Vol. 5(14), pp. 2952-2955, 18 July, 2011 Available online at http://www.academicjournals.org/JMPR ISSN 1996-0875 @2011 Academic Journals.

[20] Patani PV, Deepthi jani Seth AK, Ghaiss M M, Nihar shah, "Evaluation of antidepressant activity of Picrorhiza kurroa in mice", Journal of Pharmaceutical science and Bioscientific Research; vol-2(5): 11-17, September-October, 2012.http://www.jpsbr.org/index_htm _files/2_JPSBR_12_RS103.pdf ISSN NO. 2271-3681

[21] Rajesh Kumar, Pamitha Bhandari, Bikram Singh Abuja PS, "Evaluation of Picrorhiza Kurroa accession for growth and quality in North Western Himalayas”; Journal of Medicinal plants Research; vol-6(13), 2660-2665, $9^{\text {th }}$ April, 2012, Article Number - 01B008826714 https://doi.org/10.5897/J MPR11.1618 DOI: 10.5897/JMPR

[22] Somesh Thapliyal, Mahadevan N, Nanjan MJ, “Analysis of Picroside I and Kutkoside in Picrorhiza kurroa and it's formulation by HPTLC”, International Journal of Research in Pharmaceutical and Biomedical Sciences 2012 Vol.3 No.1 pp.25-30 ref.13, ISSN: 2229-3701URL: http://www.ijrpbsonline.com/files/06-... , Record Number: 20123216655

[23] Mohammed Rageeb Mohammed Usman, Yamgar Surekha, Gadgoli Chhaya, Slaikhe Devendra, "Preliminary screening and Antimicrobial activity of Picrorhiza kurroa Royle ex Benth. ethanolic extracts ", International Journal of Pharmaceutical Science; vol-14(1) (15), 73-76, 2012.https://globalresearchonline.net/journalcontents/v141/15.pdf ISSN 0976 - 044X 
[24] http://ntp.niehs.nih.gov/iccvam/supp/feddocs/OECD/OEC D_gl423.pdf

[25] Empress standard operating procedure, (I.P.G.T.T.) of glucose tolerance test

[26] Mutalik, S.B.Sulochana, M.Chetana, N.Udupa and U.P.Devi, 2003. Preliminary studies on acute and sub acute toxicity of antidiabetic herbal preparation, dianex, Indian Exp. https://pubmed.ncbi.nlm.nih.gov/15255640/ Biol.,41:316-320 PMID: 15255640

[27] Rang and Dale H.P., Dale M.M., Ritter J.M., and Moore P.K. 2003. The endocrine pancrease and the control of blood glucose, in Pharmacology. (Fifth edition) 380-393.

[28] A.K.Dolui and Rupa Sengupta, antihyperglycemic effect of different solvent extracts of cajanus cajan and HPLC profile of the active extracts. Asian J Pharm Clin Res, Vol 5 Issue 2, 2012, 116-119 https://www.researchgate.net/publication/2 86554554_Antihyperglycemic_effect_of_different_solvent _extracts_of_leaves_of_Cajanuscajan_and_HPLC_profile_ of_the_active_extracts.

[29] Lenzen S, Panten U. Alloxan History and mechanism of action. Diabetologia 1988; 31:337-342. https://pubmed.ncbi.nlm.nih.gov/3046975/ PMID: 3046975 doi: 10.1007/BF02341500
[30] Oberley LW. Free radicals and diabetes. Free Rad Biol Med 1988;5(2):113-24.doi: 10.1016/0891-5849(88)90036-6. https://pubmed.ncbi.nlm.nih.gov/3075947/

[31] Jorns A, Munday R, Tiedge M, Lenzen S. Comparative toxicity of alloxan, $\mathrm{N}$-alkyl-alloxans and ninhydrin to isolated pancreatic islets in vitro. J Endocrinol 1997 Nov; 155(2):283-293. https://pubmed.ncbi.nlm.nih.gov/9415063 /PMID: 9415063DOI: 10.1677/joe.0.1550283

[32] Ledoux SP, Woodley SE, Patton NJ, Wilson LG. Mechanism of notrosourea-induced $\beta$-cells damage-alterations in DNA. Diabetes 1986; 35: 866-872.

[33] Szkudelski T. The mechanism of Alloxan and Streptozotocin action in B cells of the rat pancreas. Physiol Res 2001; 50:537-546.https://pubmed.ncbi.nlm.nih.gov/11 829314/PMID: 11829314

[34] Gupta V., Jadhav J. K., Masirkar V. J., Deshmukh V. N.Antihyperglycemic effect of Diospyrosmelanoxylon (Roxb.) bark against Alloxan-induced diabetic rats. International Journal of PharmTech Research CODEN (USA): IJPRIF ISSN: 0974-4304 Vol.1, No.2, pp 196-200, April-June 2009. https://sphinxsai.com/pdf/jpt_Ap_Ju_09/ PT=16(196-200).pdf. ISSN: 0974-4304 